\title{
Creative Learning Model to Support Senior High Students in Reading Comprehension
}

\author{
Ririn Pusparini \\ Universitas Negeri Surabaya \\ Surabaya, Indonesia \\ ririnpusparini@unesa.ac.id
}

\author{
Esti Kurniasih \\ Universitas Negeri Surabaya \\ Surabaya, Indonesia \\ estikurniasih@unesa.ac.id
}

\begin{abstract}
Although many approaches and learning models have been implemented in teaching English, the learning objectives of teaching English have not been achieved maximally. One of the causes is the inappropriateness of models/methods/techniques implemented. It happens in teaching and learning process, especially on teaching reading, whereas a teacher tends to do evaluation or testing directly without guiding students to comprehend the text. Because of that, the creative learning model, that is a model that combines the model suggested by 2013 curriculum and another model/method/technique/strategy, have been developed by a student of in-service teaching program on reading skill in Senior High (SMA). The combination of scientific approach (SA), discussion, collaboration, and visualization has been conducted on the right steps or procedures. In the stage of collecting the data, teacher discusses deeply the general information and specific information before asking the students to do the task. Moreover, in teaching and learning process, creative thinking or critical thinking has been conducted started from pre-activities whereas students are supported to think creatively by doing prediction and hypothesis related to the materials that will be learned. The critical thinking in whilst-activities is seen clearly while students give simple explanation, conclusion, opinion, and find an alternative solution. Those can be categorized in cognitive level as analysis (C4), evaluation (C5), and creation (C6) (Anderson and Krathwohl, 2001).
\end{abstract}

Keywords—creative teaching model; reading comprehension

\section{INTRODUCTION}

English skills is divided into two, receptive and productive skills. One of the language learning principles says that receptive skills always come first before productive skills. It means that students have to be able to understand the language before using it in spoken and written. One of the receptive skills, reading, is considered as the most important skill. It is because by reading, students will get a lot of information that they need. Kasbolah (1988) says that reading for getting information is very important, and reading competence in English is a key to get success to open the window of the world.

In teaching and learning process, there are six learning sources that are very important, those are message, teacherstudents, materials, media, method/model/technique, and behaviour Sudjimat (1994). It means that learning model/method/technique is the one that can not be ignored by a teacher. Furthermore, Suyitno (2009) says that learning model is a set of learning procedures implemented by a teacher, so that the learning objectives or competencies expected can be achieved effectively and efficiently. Therefore, it can be said that models/methods/techniques/strategies can determine the success of learning. However, in order to implement the learning model effectively, a teacher should pay attention on the students' condition, materials, and provided learning sources.

In teaching reading in class, a teacher has already used various approaches, models, techniques, and strategies. All of them are applied in order to help students to understand the reading texts well. Based on 2013 curriculum, there are five learning models suggested for teaching English in class, those are scientific approach, genre based, problem based, discovery, and project based. Although many kinds of approaches and learning models have been conducted in class, the learning objectives have not been achieved maximally. Selecting and implementing inappropriate models/methods/techniques/strategies becomes one of the problems. It makes the teaching and learning process conducted by a teacher tends to achieve the target of materials in curriculum, not to achieve the comprehension level. It can be seen from the fact that in reading class, a teacher gives students a reading text, asks them to read the text and do the tasks. On other words, teacher tends to do evaluation straightly, and not preceded by teaching or guiding them on how to comprehend the text. As a result, students become passive and only answer the questions or do the task without comprehending the text fully. Here, it is obvious that teacher needs a learning model that can help students to be more active to participate in learning process. Hegde (2003) says that in teaching reading, a teacher needs to focus not only on reading texts, but also on how to make students understand the text well. It is also supported by the government (Government Decree No. 19/2005) that teaching learning process is conducted interactively, aspirational, and challenging to motivate students to participate actively, and to give enough space for creativity, aspiration, and independent as the students' interest, need, and development. In short, a teacher should be able to select an appropriate learning model for students in order to motivate and build students' creativity during the learning process of comprehending the text.

Then, creative learning model seems to the appropriate model for students of senior high in reading class in order to 
help them to have creativity, those are critical thinking and problem solving (Campbell, 1986). This model can be implemented in class by combining two or more learning models or methods or techniques or strategies, such as scientific approach (SA) and genre based approach (GBA) or $\mathrm{SA}$ and discussion technique. Furthermore, model/method/technique also can be combined with strategies. There are some strategies in comprehending the text, those are; brainstorming, questioning-answer relationship, visualization, and summarizing (Torres, 2005). Finally, because of the importance of creative learning model for students to comprehend the reading text, this paper will describe the implementation of creative learning model in class and how this model can support students of senior high in reading comprehension.

\section{METHODS}

This paper is a descriptive-qualitative research because the aim of the research is to describe the implementation of creative learning model in reading class for Senior high students. Furthermore, this aim is divided into two, those are; to describe the implementation of creative learning model in reading class and to describe of how this learning model can help students of senior high to explore their critical thinking. The subject of the research is the student of in-service education program. Here, she is a teacher who conducted the creative learning model in reading class. The instruments used in the research are a handy cam, an observation sheet or a rubric of the implementation of creative learning model in reading class, and a rubric of critical thinking.

In collecting the data, the researchers conducted some steps, those are; (1) the researchers came to school to ask permission to collect the data, (2) they researchers sat on the back in order not to disturb the teaching learning process in class, and (3) the researchers recorded all the activities in class by using handy cam. Moreover, for analyzing the data, the researchers conducted several steps as follows; (1) researchers observed the learning video, (2) researchers analyzed the data by using the provided instruments, (3) the researchers discussed together the results of analyzing the data; (4) the researchers drew a conclusion; and (5) the researchers started to present the result.

\section{RESULTS AND DISCUSSION}

\section{A. The Implementation of Creative Learning Model on} Reading Comprehension in Class

The teaching and learning process by implementing the creative learning model had been conducted by the teacher. Related to the creative learning model, the teacher combined the method of Scientific approach (SA) with the discussion technique, collaboration, and visualization.

The implementation of SA seems to be an appropriate method for students, in terms of students' characteristics and materials. It means that students looked comfortable and enjoy the learning process, and also the materials, that is about narrative text, can be delivered by the teacher well. The teacher had already implemented the method in correct procedures or stages, those are observing, questioning, collecting the data, associating, and communicating (Government Decree No. 22/2016), and it was combined with a certain model, technique, and strategy, those are discussion, collaboration, and visualization. The implementation of this creative learning model is as follows;

\section{a) Pre-Activities}

The teacher had conducted the pre-activities well. Beside greetings, taking attendance list, preparing students condition, the teacher had conducted the brainstorming activities well, one of them is asking students to predict the content of text by looking at the title of the text. These activities are very important to shape the students' prior knowledge and connect the students' knowledge with the new one in hoped that students will not get difficulties on the materials given (Carrel and Eisterhold in Long and Richards, 2001).

\section{(b) Whilst-Activities}

The activities are conducted by asking the students to observe the text related to social function, text structure, language features, and detailed information in the text. These activities are followed by questioning stage in which the students formulated creatively simple questions related to language features of the text. The answers of their questions were discussed by the class in order to fish the students able to give simple explanations. In this case, students were supported to be able to find key terms of the text, as Widana (2007) says that knowing the meaning of words that are rarely used are difficult, but it is not included to High-Order Thinking Skills (HOTS) unless it is involved with the analysis process, for finding the meaning of words from the context or contextually. Furthermore, the stage of collecting the data was also conducted well. Here, the teacher guided the students to comprehend the text at first instead of testing or evaluating. The questions, such as; "What do you think about what the king has done?" If you were a king, Would you do the same thing as the king did in the story?" What can you learn from the story?" showed that the teacher taught the students on how to comprehend the text, those are finding the message of the text and solution of a problem. In this case, students are not only taught to communicate in the target language, but also to solve the problem (Elaine Johnson, 2002: 183). For associating and communicating stage, the teacher asked the students to complete the story map and retold that story map. Through this activity, the students' creativity were obvious seen because they directly used the target language in elaborating and telling the story through the story map that they have made. Appreciation in the form of a big applause and compliment were given by the teacher after they retold the text or the story for giving them motivation in communicating the target language (Elaine Johnson, 2002: 183). 
(c) Post-Activities

In this stage, the teacher had supported the students to think critically, those are by asking the students to explain what they had learned and what they could learn from the materials that day.

\section{B. The Implementation of Creative Learning Model in Reading Class to Support Students' Critical Thinking}

Creative learning model on reading activities had helped students to explore their critical thinking. It was conducted since pre-activities whereas the teacher had supported the students to think critically by making the hypothesis or prediction related to the materials that they learned; "Have you ever heard a story from Kalimantan?", "The story related to lake and animals...animal that has long feet, it can fly, ....", "Can you predict what the story is from the title?".

The critical thinking was also seen clearly in whilstactivities. This could be seen from the teacher's questions, such as; What do you think about what the king has done?" If you were a king, Would you do the same thing as the king did in the story?" What can you learn from the story?". Those questions were meant to guide students able to make analysis, give the conclusion, make argument, and formulate the alternative solution. All of those activities have fulfilled the concept of critical thinking, that is in-depth thinking process whereas it can support the students to be independent to solve the problems and to make decision of something they believe in. It is supported by Ustinlilog (2004) that students are given a big chance to develop their knowledge and solve the problems. Another activity that can be seen clearly in supporting students to think critically and creatively is the activity of elaborating the story map. Through this activity, students are able to observe, analyze, solve the problem, and get an idea to help them to communicate in the target language (Hughes, 2014).

\section{CONCLUSION}

Based on the discussion, it can be concluded that the implementation of creative learning model in reading class had been conducted well and in right procedures by the teacher. Here, the teacher combined Scientific Approach (SA) with discussion technique, collaboration, and visualization. Moreover, this creative learning model had been able to support students' critical thinking skill by making prediction or hypothesis related to the materials learned. The students' critical thinking is seen more clearly in whilst-activities whereas they are guided to give simple explanations, build basic knowledge, make conclusion, give deep explanation, and make strategy (Lawson, 1976). They can be categorized into the cognitive level of analysis (C4), evaluation (C5), and creating (C6) (Anderson and Krathwohl, 2001).

\section{REFERENCES}

[1] Abbot, Gery, John G, Douglas M, Peter W, "The Teaching of English as an International Language. Practical Guide," Great Britain: William Collins Sons and Co.Ltd. 1981.

[2] Anderson and Krathwoh, Revised Bloom's Taxonomy. QuestionStarters, 2001.

[3] Campbell, 1986

[4] Elaine Johnson, 2002

[5] Facione, P.A. and Facione, N.C, Holistic Critical Thinking Scoring Rubric. Millbrae, CA: California Academic Press. www.calpress.com/rubric.html (retrieved September 2003). 1994.

[6] Hedge, T, Teaching and learning in the Language Classroom, 2-24. 2003.

[7] Hughes, J, Critical thinking in the Language Classroom, ELI, 2004.

[8] Kasbolah, "A Syllabus for the Course in Teaching/Learning Strategies for Students of English Education in Indonesia". Unpublished Dissertation, University of Kansas, 1987.

[9] Krahnke, K, Approaches to Syllabus Design for Foreign Language Teaching, London: Prentice-Hall International, Ltd, 1987.

[10] Lawson, 1976.

[11] Permendikbud, Peraturan Menteri Pendidikan dan Kebudayaan No. 21 Tahun 2016, 2016

[12] Permendikbud, Peraturan Menteri Pendidikan dan Kebudayaan No. 22 Tahun 2016, 2016.

[13] Richards, J..C, Longman Dictionary of Applied Linguistics. England: Longman Group Limited, 1985.

[14] Richards, J.C, Curriculum in Language Teaching,. New York: Cambridge University Press, 2001.

[15] Sudjimat, D.A, Pengembangan Buku Teks untuk Memudahkan Belajar. Jurnal Pendidikan Humaniora dan Sains, Vol. 1 No. 1 hlm 29-37, 1994.

[16] Suyitno, 2009

[17] Thiagarajan, S., Semmel, D.S., \& Semmel, M.I, Instructional Development for Training Teachers of Expectional Children Minneapolis, Minnesota: Leadership Training Institute/Special Education, University of Minnesota. 1974.

[18] Torres, N.G, Improving Reading Comprehension Skills through Reading Strategies used by a Group of Foreign Language Learners. December 2009. 55-70, 2005.

[19] Widana, I.W, Modul Penyusunan Soal Higher Order Thinking Skills (HOTS), Jakarta: Kementrian Pendidikan dan Kebudayaan, 2007.

[20] Ustinlilog 'Lu, E, Language Teaching through Critical Thinking and Self-Awareness, English Teaching Forum, 2004. 